\title{
SIMULTANEOUS RP-HPLC-DAD DETERMINATION OF DANSYL AMINO ACIDS IN CHEMICALLY TREATED HUMAN HAIR
}

\author{
Pece Sherovski, Marina Stefova, Natasha Ristovska \\ Institute of Chemistry, Faculty of Natural Sciences and Mathematics, \\ Ss. Cyril and Methodius University, Skopje, Republic of Macedonia \\ sherovski.p@hotmail.com
}

\begin{abstract}
A simple, rapid, and reliable reversed phase high-performance liquid chromatographic (RP-HPLCDAD) method for the analysis of 19 amino acids in the protein hydrolysate of chemically treated hair was developed. The pre-column dansylation and RP-HPLC separation were optimized and peak resolution was improved as compared to previously published HPLC methods. The developed method showed excellent linearity for all tested amino acids in the concentration range $0.05-0.5 \mathrm{mmol} / \mathrm{l}$. The obtained results show that the concentration of all amino acids detected in bleached hair decreases with increasing hydrogen peroxide concentration. This is most significant for cystine compared to virgin hair. Higher amounts of the typical amino acids of keratin were measured after exposure of hair to protein treatments. The method has been shown to be very useful for amino acid analysis in the protein hydrolysate and it can also be used for establishing the amino acid profiles of other protein samples using this optimized procedure.
\end{abstract}

Keywords: HPLC; dansyl amino acids; protein hydrolysate; hair proteins; bleaching; protein treatments

\section{СИМУЛТАНО ОПРЕДЕЛУВАЊЕ НА ДАНСИЛ-ДЕРИВАТИ НА АМИНОКИСЕЛИНИ CO RP-HPLC-DAD ВO ХЕМИСКИ ТРЕТИРАНА КОСА}

\begin{abstract}
Развиен е едноставен, брз и сигурен метод за анализа на 19 аминокиселини во протеински хидролизати од хемиски третирана коса со примена на реверзнофазна високоефикасна течна хроматографија (RP-HPLC-DAD). Оптимизирани се процесите на претколонска дериватизација со дансил хлорид и потоа сепарација со RP-HPLC, при што резолуцијата на пиковите е подобрена во однос на претходно објавените методи HPLC. Развиениот метод покажува одлична линеарност за сите тестирани аминокиселини во концентрациската област од 0.05 до $0.5 \mathrm{mmol} / \mathrm{l}$. Добиените резултати покажуваат дека концентрацијата на сите аминокиселини во бланширана коса се намалува со зголемување на концентрацијата на водород пероксидот. Оваа промена е најзначителна кај цистинот во споредба со нетретирана коса. Поголеми количества од аминокиселините типични за кератинот се измерени по изложување на косата на протеински третмани. Овој оптимизиран метод е многу погоден за анализа на аминокиселините во протеински хидролизати и може да се користи за утврдување на аминокиселинските профили и на други примероци кои содржат протеини.
\end{abstract}

Клучна зборови: HPLC; дансил-деривати на аминокиселини; протеински хидролизати; протеини во коса; бланширање; протеински третмани

\section{INTRODUCTION}

Hair is a very unique personal feature that plays an essential role in self-perception and it can easily be changed in terms of length, color and shape. However, common chemical cosmetic treatments, such as permanent waving, bleaching and dyeing, routine hair care treatments, and even 
exposure to UV irradiation, may induce significant changes in hair cuticle and cortex and damage the fiber. This damage can affect only the hair fiber surface attributes, such as smoothness, porosity, and shine, or it can affect the fiber core texture (thickness) and mechanical properties. The abrasion and morphological change in the surface structure of human hair has previously been widely investigated using microscopic techniques, such as scanning electron microscopy (SEM) [1-3], transmission electron microscopy (TEM) [4], and atomic force microscopy (AFM) $[5,6]$. Optical coherence tomography (OCT) is another non-invasive reliable scientific technique that was recently used to study and characterize the ultra-morphology of human hair treated with cosmetic products [7].

The main components of human hair are keratin proteins corresponding to $65-95 \%$ of the hair weight, depending on its moisture content. Alpha-keratins (60\% of total hair proteins) are divided into two subfamilies of type I acidic proteins (40-50 kDa) and type II neutral/basic proteins (55$65 \mathrm{kDa}$ ), and they are mainly found in $\alpha$-helix conformations. Keratin associated proteins (KAPs) do not demonstrate well-defined spatial organization and their classification is based on amino acid content into high-sulfur proteins $(10-20 \mathrm{kDa})$ and ultra-high-sulfur proteins (10-20 kDa) characterized with high cystine residue content (30-40\%) and high-glycine/tyrosine proteins $(6-9 \mathrm{kDa})$ [8]. The various characteristic absorption frequencies of the predominant $\alpha$-helical keratin protein of hair fiber are well established by infrared spectroscopy. The combination of IR microspectroscopy (IMS) and synchrotron radiation was used to study the effect of bleaching since it can allow differentiation of the morphological units of hair fiber, cuticle, cortex and medulla with chemical resolution of only a few microns [9]. In addition, cosmetic treatments of human hair (reduction, heating, and oxidation) cause partial disruption of the helical structure in cystine rich keratin intermediate filament (KIF), which has been characterized by an assortment of other spectroscopic techniques, such as Raman spectroscopy [10], X-ray photoelectron spectroscopy [11] and solid-state nuclear magnetic resonance (NMR) [12]. Some of these techniques require expensive instrumentation, some are qualitative, and others lack sensitivity and precision required for a routine analytical method for studying hair surface damage.

Quantitative measurement of protein loss during abrasion/erosion can serve as a sensitive method for studying hair damage. Many spectrophotometric methods, such as the Lowry [13], Bradford [14, 15] and BCA (bicinchoninic acid) methods [16], have been suggested for determination of total protein in hair and applied in investigations of the properties and effects of cosmetic products on hair fiber. The effects of chemical cosmetic treatments, light exposure, and combinations of these processes on the protein composition of hair have also been evaluated by sodium dodecyl sulfate-polyacrylamide gel electrophoresis SDS-PAGE $[17,18]$. The change in the protein composition of hair fiber is due to the breakage of the cysteine disulfide bonds and cross-links that the sulfur-rich amino acid cysteine forms with other proteins, thus forming new bands of proteins with low and high molecular weights that can be detected.

Hair proteins, keratins type I and II, and keratin-associated proteins (KAPs) are built from a specific composition of amino acids. The amino acid composition of human hair keratins is significantly different from the other keratins, particularly in regards to cystine and glycine content [19]. The higher amount of cystine $(7.6 \%$ in human hair keratin and $2.9 \%$ in keratin in the epidermis outermost layer) means more disulfide and cross-linked bonds, which confers structural strength and rigidity of hair fiber, especially of the cuticle A-layer with approximately $30 \%$ cystine. In the hydrolysates of the cuticle, there are also large amounts of serine, proline, glutamic acid, valine and glycine [2]. KAPs include proteins with high cystine, glycine, and tyrosine content. The free amino acid content increases on the fiber surface with exposure to UV light and exposure to bleaching chemicals as breakdown products from the hair proteins. For further investigation of changes in protein composition of hair and explanation of the possible mechanisms of action of hair care cosmetics, amino acid analysis of hair proteins is necessary.

Amino acid analysis can be used for the determination of the amounts of free amino acids in a sample or the relative composition of amino acids in peptides and protein samples after hydrolysis. Amino acids are non-volatile compounds, and they have been commonly separated and determined by liquid chromatography (LC). Since they have neither fluorescence nor strong absorbance in the ultraviolet/visible region, their detection is quite difficult and requires specific instrumentation and detectors, such as evaporative light scattering (ELS), chemiluminescent nitrogen (CLN) and mass spectrometric (MS) detection [20]. Amino acids can be determined either by pre-column or post-column derivatization using UV chromophore or fluorophore reagents. Improved selectivity and sensitivity have been reported for highperformance liquid chromatographic (HPLC) determination of amino acids in biological samples 
based on pre-column derivatization with various reagents, such as phenylisothiocyanate (PITC), ophthalaldehydes (OPA), dansyl chloride (Dns-Cl), dabsyl chloride (Dbs-Cl), fluorescamine, 9fluorenylmethyl-chloroformate (FMOC-Cl), 1fluoro-2,4-dinitrobenzene, and 1-fluoro-2,4-dinitrophenyl-5-L-alanine amide, or by post-column derivatization with ninhydrin or OPA using commercially available amino acid analyzers [21-23].

Each of these reagents have particular advantages and limitations. The derivatization methods, post-column with OPA and pre-column with Dns-Cl, are suitable for quantification of amino acids in the nanomolar concentration range, while in the lower picomolar range better results have been obtained by derivatization with Dns-Cl. In addition, dansyl and dabsyl derivatives are very stable compared to products formed by OPA [20]. Both Dns-Cl and Dbs-Cl react with primary and secondary amines, whereas OPA does not react with secondary amino acids, such as proline and hydroxyproline. More recently, a new reagent, $\mathrm{N}$ hydroxysuccinimidyl- $\alpha$-naphthylacetate (SINA), has been reported for fluorescence-based amino acid detection in the femtomolar concentration range [24].

Here, we describe a reversed phase HPLC method that has been developed for simultaneous separation and quantification of dansyl derivatives of hair protein amino acids. The aim of this study was to develop a suitable method with the needed sensitivity and to demonstrate its applicability in measuring hair damage caused by bleaching and dying, as well as to demonstrate the efficacy of different cosmetic protein treatments based on hydrolyzed keratin.

\section{MATERIALS AND METHODS}

\subsection{Chemical, standard and reagent preparation}

Dansyl chloride (1- $N, N^{\prime}$-dimethylaminonaphthalene-5-sulfonyl chloride) with $99.0 \%$ purity and amino acids (asparagine, aspartic acid, glutamic acid, serine, threonine, glycine, alanine, arginine, proline, valine, methionine, leucine, cysteine, tryptophan, phenylalanine, cystine, lysine, histidine, and tyrosine) were from Sigma (Steinheim, Germany). HPLC-grade acetonitrile was purchased from Carlo Erba (Cornaredo, Italy). Hydrochloric acid and the organic solvents chloroform, methanol, and ethanol were supplied by Merck (Darmstadt, Germany) with purities $\geq 99.9 \%$. Sodium carbonate (p.a.) and sodium acetate (p.a.) were from Merck Alkaloid (Skopje, Macedonia). Dou- ble deionized water $\left(\mathrm{ddH}_{2} \mathrm{O}\right)$ with a conductivity of $0.3 \mu \mathrm{S} / \mathrm{cm}$ was used.

Stock standard solutions of amino acids $\left(0.01 \mathrm{~mol} / \mathrm{dm}^{3}\right)$ were prepared by adding an accurately weighed amount of each amino acid to a 10 $\mathrm{ml}$ volumetric flask and then filling to volume with $0.01 \% \mathrm{HCl}$. For quantification, four-point calibration curves for each amino acid were constructed in the range shown in Table 1. Standard mixtures with amino acid concentrations of $0.1 \mathrm{mmol} / \mathrm{dm}^{3}$, $0.2 \mathrm{mmol} / \mathrm{dm}^{3}, 1 \mathrm{mmol} / \mathrm{dm}^{3}$ and $2 \mathrm{mmol} / \mathrm{dm}^{3}$ were prepared and stored at $4{ }^{\circ} \mathrm{C}$ until further use. Due to its stability, the derivatization agent Dns-Cl was prepared by dissolving $1 \mathrm{~g}$ Dns- $\mathrm{Cl}$ in $10 \mathrm{ml}$ acetone. Before use, $2 \mathrm{ml}$ of this solution was dissolved in $10 \mathrm{ml}$ of acetonitrile and used for the derivatization reaction. A solution of $\mathrm{Na}_{2} \mathrm{CO}_{3}(0.4$ $\mathrm{mol} / \mathrm{dm}^{3}$ ) with $\mathrm{pH} 9$ was prepared.

\section{$\mathrm{T}$ a b l e 1}

Calibration curve equations and correlation coefficients for amino acids in the 0.05-0.5 $\mathrm{mmol} / \mathrm{dm}^{3}$ concentration range (in the final mixture after derivatization)

\begin{tabular}{|c|c|c|c|}
\hline Amino acid & Abbreviation & $\begin{array}{c}\text { Calibration curve } \\
\text { equation }\end{array}$ & $\mathrm{R}^{2}$ \\
\hline $\begin{array}{l}\text { Aspartic } \\
\text { acid }\end{array}$ & Asp & $y=8.1 \cdot 104 x+150.7$ & 0.9990 \\
\hline $\begin{array}{l}\text { Glutamic } \\
\text { acid }\end{array}$ & Glu & $y=1.1 \cdot 106 x+91.76$ & 0.9984 \\
\hline Asparagine & Asn & $y=2.7 \cdot 106 x+58.72$ & 0.9985 \\
\hline Serine & Ser & $y=2.7 \cdot 106 x+13.35$ & 0.9984 \\
\hline Threonine & Thr & $y=2.9 \cdot 106 \times 24.52$ & 0.9983 \\
\hline Glycine & Gly & $y=4.1 \cdot 106 x+7.73$ & 0.9988 \\
\hline Alanine & Ala & $y=2.7 \cdot 106 x+8.85$ & 0.9977 \\
\hline Arginine & Arg & $y=2.6 \cdot 106 x+16.78$ & 0.9973 \\
\hline Proline & Pro & $y=2.0 \cdot 106 x+84.91$ & 0.9982 \\
\hline Valine & Val & $y=4.1 \cdot 106 x+90.29$ & 0.9992 \\
\hline Methionine & Met & $y=2.2 \cdot 106 x+1.72$ & 0.9979 \\
\hline Leucine & Leu & $y=2.8 \cdot 106 x+94.03$ & 0.9976 \\
\hline Cysteine & Cys & $y=2.7 \cdot 106 x+17.57$ & 0.9989 \\
\hline Tryptophan & Trp & $y=4.3 \cdot 106 x+59.29$ & 0.9970 \\
\hline Phenylalanine & Phe & $y=8.9 \cdot 106 x+195.07$ & 0.9978 \\
\hline Cystine & Cys-Cys & $y=7.9 \cdot 106 x+1185.14$ & 0.9993 \\
\hline Lysine & Lys & $y=1.6 \cdot 106 x+194.20$ & 0.9984 \\
\hline Histidine & His & $y=6.2 \cdot 106 x+104.41$ & 0.9972 \\
\hline Tyrosine & Tyr & $y=1.6 \cdot 106 x+130.58$ & 0.9988 \\
\hline
\end{tabular}

\subsection{Preparation of hair samples}

Samples of human hair were collected from one woman volunteer to minimize the experimental variations that may be caused by sampling source, and the hair did not have any chemical 
treatments such as bleach, hair dyes or perms. The hair samples were washed with $75 \%$ ethanol to remove any surface contaminants. The external lipids were removed using a mixture of chloroform/methanol $(2: 1, V / V)$ for $24 \mathrm{~h}$ and dried at room temperature. Hair samples were exposed to a bleaching reagent (bleaching powder by Revlon with $6 \%, 9 \%$ and $12 \% \quad \mathrm{H}_{2} \mathrm{O}_{2}$ ) and hair dye (Alfaparf Milano and $6 \% \mathrm{H}_{2} \mathrm{O}_{2}$ ) for $45 \mathrm{~min}$, washed with $\mathrm{ddH}_{2} \mathrm{O}$ and air dried. Samples obtained after usage of bleaching powder and 12\% $\mathrm{H}_{2} \mathrm{O}_{2}$, were treated with Fibreplex and Fibreforce by Schwarzkopf and Keratin treatment by Revlon for $30 \mathrm{~min}$. Then, hair samples were cut into small pieces with lengths of approximately $1-2 \mathrm{~mm}$.

Hydrolysates were prepared from each group of hair samples treated with the different chemical treatments listed in Table 2. For that purpose, the measured mass of hair was treated with 6 $\mathrm{ml}$ of $6 \mathrm{M} \mathrm{HCl}$ and refluxed for $24 \mathrm{~h}$ at $105^{\circ} \mathrm{C}$. Then, the mixture was filtered through Whatman 1 filter at high temperature, followed by decolorization of the liquid phase for $0.5 \mathrm{~h}$ at $80{ }^{\circ} \mathrm{C}$ using active carbon. After another filtration, the obtained filtrate was transferred to a $10 \mathrm{ml}$ volumetric flask and filled to volume with $\mathrm{ddH}_{2} \mathrm{O}$.

\section{Table 2}

Preparation of hydrolysates from different treated human hair samples

\begin{tabular}{lccc}
\hline Hair samples & $\begin{array}{c}\text { Mass of } \\
\text { hair } \\
(\mathrm{g})\end{array}$ & $\begin{array}{c}6 \mathrm{M} \\
\mathrm{HCl} \\
(\mathrm{ml})\end{array}$ & $\begin{array}{c}\text { Total } \\
\text { volume } \\
(\mathrm{ml})\end{array}$ \\
\hline Untreated hair & 0.1412 & 6 & 10 \\
\hline $\begin{array}{l}\text { Bleached hair with } \\
6 \% \mathrm{H}_{2} \mathrm{O}_{2}\end{array}$ & 0.1500 & 6 & 10 \\
\hline $\begin{array}{l}\text { Bleached hair with } \\
9 \% \mathrm{H}_{2} \mathrm{O}_{2}\end{array}$ & 0.1600 & 6 & 10 \\
\hline $\begin{array}{l}\text { Bleached hair with } \\
12 \% \mathrm{H}_{2} \mathrm{O}_{2}\end{array}$ & 0.1500 & 6 & 10 \\
\hline $\begin{array}{l}\text { Dyed hair } \\
\text { (Alfafare) }\end{array}$ & 0.1200 & 6 & 10 \\
\hline $\begin{array}{l}\text { Protein treatment } \\
\text { (Fibreforce) }\end{array}$ & 0.1214 & 6 & 10 \\
Schwartskopf & 0.0976 & 6 & 10 \\
\hline $\begin{array}{l}\text { Protein treatment } \\
\text { (Fibreplex) } \\
\text { Schwartskopf }\end{array}$ & 0.1750 & 6 & 10 \\
\hline $\begin{array}{l}\text { Protein treatment } \\
\text { (Keratin treatment) } \\
\text { Revlon }\end{array}$ & & \\
\hline \hline
\end{tabular}

The derivatization reaction was then carried out by adding $0.5 \mathrm{ml}$ hydrolysate or previously prepared standard solutions of amino acids (0.1 $\mathrm{mmol} / \mathrm{dm}^{3}, 0.2 \mathrm{mmol} / \mathrm{dm}^{3}, 1 \mathrm{mmol} / \mathrm{dm}^{3}$ and 2 $\mathrm{mmol} / \mathrm{dm}^{3}$ ) to $1 \mathrm{ml}$ of a freshly prepared acetonitrile solution of Dns-Cl $(20 \mathrm{mg} / \mathrm{ml})$, followed by the addition of $0.5 \mathrm{ml}$ of a $\mathrm{Na}_{2} \mathrm{CO}_{3}$ solution $(0.4$ $\mathrm{M})$ to adjust the $\mathrm{pH}$ to 9 . The mixture was heated in a water bath for $1 \mathrm{~h}$ at $70{ }^{\circ} \mathrm{C}$. After derivatization, the reaction vials were left to cool at room temperature, filtered with a $0.45 \mu \mathrm{m}$ polytetrafluoroethylene filter (Agilent PTFE), and injected directly into the HPLC system.

\subsection{HPLC-DAD analysis}

The HPLC-DAD system was an Agilent 1100 series (Agilent Technologies, Waldbronn, Germany) consisting of a quaternary pump, autosampler, degasser and a photodiode array detector (DAD) controlled by ChemStation software (Agilent, v.08.03). Dansyl amino acids were separated on an Eclipce XDB C18 column $(150 \mathrm{~mm} \times$ $4.6 \mathrm{~mm}, 5 \mu \mathrm{m})$ at $30^{\circ} \mathrm{C}$. For the separation, gradient elution of two solvents was used: Solvent A was $10 \mathrm{mM}$ sodium acetate in 5\% acetonitrile with pH 6.3 and solvent $\mathrm{B}$ was acetonitrile. The gradient program was the following: $0 \mathrm{~min}, 5 \% \mathrm{~B} ; 10-15$ min, $15 \%$ B; $25 \mathrm{~min}, 20 \% \mathrm{~B} ; 40 \mathrm{~min}, 90 \% \mathrm{~B}$ (total run time of $40 \mathrm{~min}$ ). The flow rate was $1.0 \mathrm{ml} / \mathrm{min}$ and the injection volume was $5 \mu \mathrm{l}$. Monitoring of dansyl amino acids was performed at $214 \mathrm{~nm}, 220$ $\mathrm{nm}$, and $250 \mathrm{~nm}$, while quantification was performed at $250 \mathrm{~nm}$. Peak identification was based on the comparison between the retention time of the standards of the dansyl amino acids and those in hydrolysate.

\section{RESULTS AND DISCUSSION}

A variety of HPLC techniques for separation and estimation of amino acids, mainly of protein hydrolysates, have been reported [20]. HPLC methods have the advantage of being accessible to most analytical laboratories since they do not require expensive dedicated instruments, such as the classical method based on ion-exchange chromatography coupled with post-column derivatization using the ninhydrin reaction (amino acid analyzer). However, there are some disadvantages as a result of the instability of the derivatives that are rapidly degraded (OPA derivatives) or the unsatisfactory derivatization of the secondary amino acids. Therefore, pre-column derivatization using dansyl chloride (Dns-C1) or dabsyl chloride (Dbs-Cl) has been applied for amino acid analysis by HPLC coupled with UV absorbance or fluorescence detectors [22, 25]. Pre-column derivatization of amino acids with Dns-Cl yields sulfonamide adducts that are in- 
tensely fluorescent and highly resistant to acid and alkaline hydrolysis. The dansylation reaction is economical, lacks reagent interference, and Dns-Cl also reacts with secondary amino acids. Therefore, a modified dansylation method for improving the sensitivity of UV detection of amino acids in hydrolyzed human hair samples (virgin, bleached, and treated with keratin treatments) was developed and optimized.

\subsection{Optimization of the procedure for dansyl derivatization}

Different concentrations of Dns-Cl (5-25 $\mathrm{mg} / \mathrm{ml}$ ), incubation temperatures $\left(60-80{ }^{\circ} \mathrm{C}\right)$, and $\mathrm{pH}$ values of the reaction medium were tested to find the optimal conditions for the dansyl derivatization reaction (Fig. 1).

The yield of Dns-amino acid under the classical conditions of the reaction (acetone/water 2:1, $\mathrm{pH} \mathrm{9,} \mathrm{sodium} \mathrm{bicarbonate} \mathrm{buffer)} \mathrm{was} \mathrm{found} \mathrm{to} \mathrm{be}$ dependent on the relative amount of Dns-Cl for some amino acids [26], while according to the Tapuhi method [27] with substitution of acetonitrile for acetone as a solvent, such a dependence was not observed. In this work, acetonitrile was used as a solvent for dansylation. Also, under these conditions several extraneous peaks resulting from Dns$\mathrm{Cl}$-acetone reaction products were eliminated.

According to the literature [27], quantitative determination of amino acids was achieved when Dns-Cl was used with 1000 -fold excess. To study the influence of the concentration of Dns- $\mathrm{Cl}$ in this work, solutions with variable concentrations were prepared as follows: $5,10,15,20$, and $25 \mathrm{mg} / \mathrm{ml}$ using a standard solution of aspartic acid $(0.133$ $\mathrm{mg} / \mathrm{ml}$ ) that corresponds to 75 to 375 -fold excess Dns-Cl. The effect of the concentration of the derivatization reagent on the peak area of Asp is presented in Figure 2. It was found that subsequent increases in the concentration of Dns-Cl over 20 $\mathrm{mg} / \mathrm{ml}$ did not cause any significant changes; therefore, this concentration was chosen.<smiles>CN(C)c1cccc2c(S(=O)(=O)Cl)cccc12</smiles><smiles>[R]C(N)CC(=O)O</smiles><smiles>[R]C(CC(=O)O)NS(=O)(=O)c1cccc2c(N(C)C)cccc12</smiles>

Fig. 1. Reaction scheme for the dansylation of amino acids

For this investigation, aspartic acid was chosen as one of the seven best recovered amino acids [28] due to its stability during acid hydrolysis and absence of multiple derivatization products. Namely, serine and threonine are degraded slightly during acid hydrolysis and the bonds between valine and isoleucine are difficult to hydrolyze. Methionine can be oxidized during hydrolysis, while glycine is a frequent contaminant due to its use in many buffers. Aspartic acid also occurs in high amounts in the cuticle and epicuticle of human hair.

It is known that reaction of primary amine groups with dansyl chloride requires an alkaline $\mathrm{pH}$, but at values above 10.0 the desired dansylation reaction is in competition with the hydrolysis of dansyl chloride by water [29]. Taking into account the recommended working $\mathrm{pH}$ values for the column (between 2 and 10) and according to our previous results for dansylation [27], a $\mathrm{pH}$ of 9.0 was chosen as optimal for further analysis of nonprotonated amine groups.

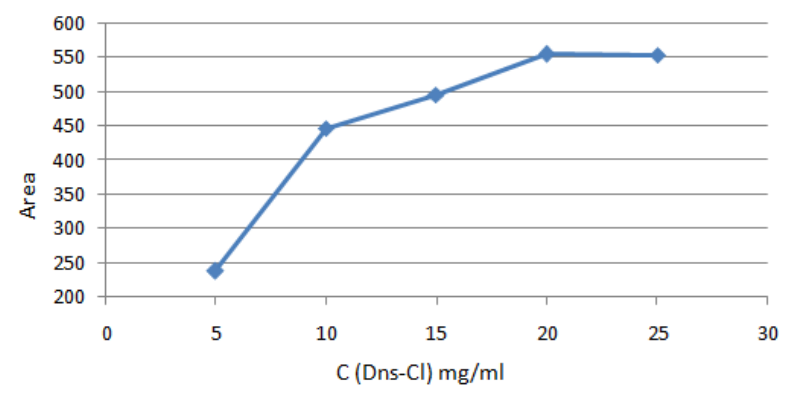

Fig. 2. Influence of the concentration of Dns-Cl on the peak area of aspartic acid 
The dansylation reaction is carried out at elevated temperatures rather than at ambient temperature. Various dansylation reaction conditions are reported, such as incubation at $60{ }^{\circ} \mathrm{C}$ for $60 \mathrm{~min}$ or at $38{ }^{\circ} \mathrm{C}$ for $90-120 \mathrm{~min}[25,30]$. In this investigation, sodium carbonate added to reach $\mathrm{pH} 9.0$ allowed for the dansylation reaction of amino acids to proceed to completion within $1 \mathrm{~h}$ at an incubation temperature of $70{ }^{\circ} \mathrm{C}$. Small variations in the temperature between 60 and $80{ }^{\circ} \mathrm{C}$ did not significantly affect the peak area obtained for Asp.

Therefore, the optimal conditions for the dansylation of amino acids were the following: using 350-fold excess dansyl chloride in $\mathrm{CH}_{3} \mathrm{CN}$ (20 $\mathrm{mg} / \mathrm{ml})$ in the presence of $\mathrm{Na}_{2} \mathrm{CO}_{3}\left(0.4 \mathrm{~mol} / \mathrm{dm}^{3}\right)$ at a pH adjusted to 9.0 at $70{ }^{\circ} \mathrm{C}$. A derivatization time of $1 \mathrm{~h}$ was proposed as sufficient for complete derivatization of all investigated amino acids in the mixture in order to obtain the highest signals of dansylated products with UV detection.

\subsection{Optimization of chromatographic conditions for analysis of dansyl amino acids}

There are a number of separation challenges in analyzing amino acids, such as compromising between high resolution, high speed, and reduced solvent consumption, or a combination of these that bests suits their quantification. Here, we report an RP-HPLC method for the analysis of amino acids with pre-column Dns-Cl derivatization and UV detection.
To develop a convenient, simple, and rapid HPLC method for quantitative analysis of amino acids in chemically treated human hair, a variety of chromatographic conditions were evaluated. Mobile phases (acetonitrile/water and acetonitrile/acetate buffer at $\mathrm{pH}$ 6.3), column temperature, flow rate, and gradient programs were optimized to achieve baseline separation and maximum sensitivity using an Eclipce XDB C18 column $(150 \mathrm{~mm} \times$ $4.6 \mathrm{~mm}$, particle size $5 \mu \mathrm{m}$ ). This column is characterized by a good peak shape for basic, acidic, and neutral compounds, such as amino acids and their derivatives, and shows excellent performance over a wide $\mathrm{pH}$ range ( $\mathrm{pH} 2-9)$.

The best separation of standard mixtures of amino acid derivatives was obtained using the mobile phase consisting of solvent A (10 mM sodium acetate in 5\% acetonitrile, $\mathrm{pH} 6.3$ ) and acetonitrile as solvent $\mathrm{B}$ with the following gradient program: $0 \mathrm{~min}, 5 \% \mathrm{~B} ; 10-15 \mathrm{~min}, 15 \% \mathrm{~B} ; 25 \mathrm{~min}, 20 \% \mathrm{~B}$; $40 \mathrm{~min}, 90 \%$ B (chromatogram shown in Fig. 3). Good peak shape was achieved when acetic buffer was used, compared to asymmetric peaks obtained in water. The UV spectra of Dns-adducts possess the same absorbance maxima at 214, 250, and 325 $\mathrm{nm}$, whereas quantification was performed at 250 $\mathrm{nm}$ to attain the needed sensitivity and good selectivity. The proposed HPLC method allowed for the simultaneous analysis of all amino acids in chemically treated human hair as Dns derivatives in the gradient elution mode within $40 \mathrm{~min}$.

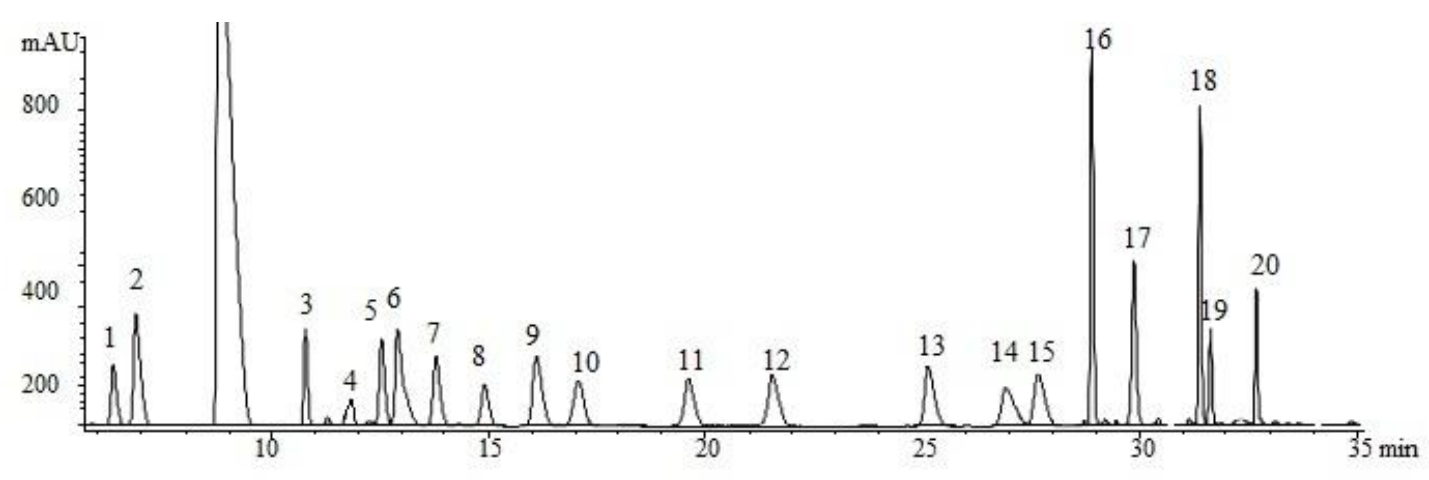

Fig. 3. HPLC chromatograms of dansyl amino acids in standard solution monitored at $250 \mathrm{~nm}$. Peak numbers are the following: 1 - Asp, 2 - Glu, 3 - Asn, 4 - Cys-Cys, 5 - Ser, 6 - Thr, 7 - Gly, 8 - Ala, 9 - Arg, 10 - Pro, 11 - Val, 12 - Met, 13 - Leu, 14 - Cys, 15 - Trp, 16 - Phe, 17 - Cys-Cys, 18 - Lys, 19 - His and 20 - Tyr.

All investigated dansyl amino acids in the standard mixture were unambiguously identified by their retention time. A representative analysis of a $1 \mathrm{mmol}$ standard amino acid mixture is shown in Figure 3, where the order of eluting compounds was with the most acidic aspartate eluting first and the tyrosine with a hydroxyl group in the aromatic ring last. The separation of the three amino acid pairs Asp/Glu [25], Ala/Arg [31], and His/Cys-Cys [32], which is usually difficult, was improved and baseline resolution of these closely migrating compounds was achieved. In the dansylation reaction, 
two dansyl derivatives of cystine were obtained, mono-dansyl aduct (peak 4) and bis-aduct (peak 17), which were identified by performing the dansylation reaction with a cystine standard solution. The major peak of cystine (peak 17) was the one used for the quantification. The excess Dns-Cl was observed as an intensive broad peak in the chromatograms $\left(t_{\mathrm{r}}=8-9.5 \mathrm{~min}\right)$ which was completely separated from the analytes without the need for further clean-up of the reaction mixture.

\subsection{HPLC analysis of dansyl amino acids in bleached human hair}

This optimized HPLC method was suitable for determining all investigated amino acids in the chemically treated hair, which may provide some information regarding the damage of the hair de- pending on amino acid composition and quality of protein treatments based on keratin hydrolysates. In this work, dansyl amino acids in virgin (Fig. 4A) and chemically treated hair (Figs. 4B, 4C) were simultaneously measured.

The primary purpose of bleaching human hair is lightening followed by oxidative degradation of melanin. However, due to the severe reaction conditions required for destruction of the pigment chromophore, side reactions with the hair proteins occur simultaneously. Hydrogen peroxide and persulphates, the fundamental ingredients of hair bleach systems, react faster with melanin than with hair proteins. However, degradation of proteins also occurs during bleaching due to the presence of a large percentage of oxidizable functional groups, such as disulfide groups.

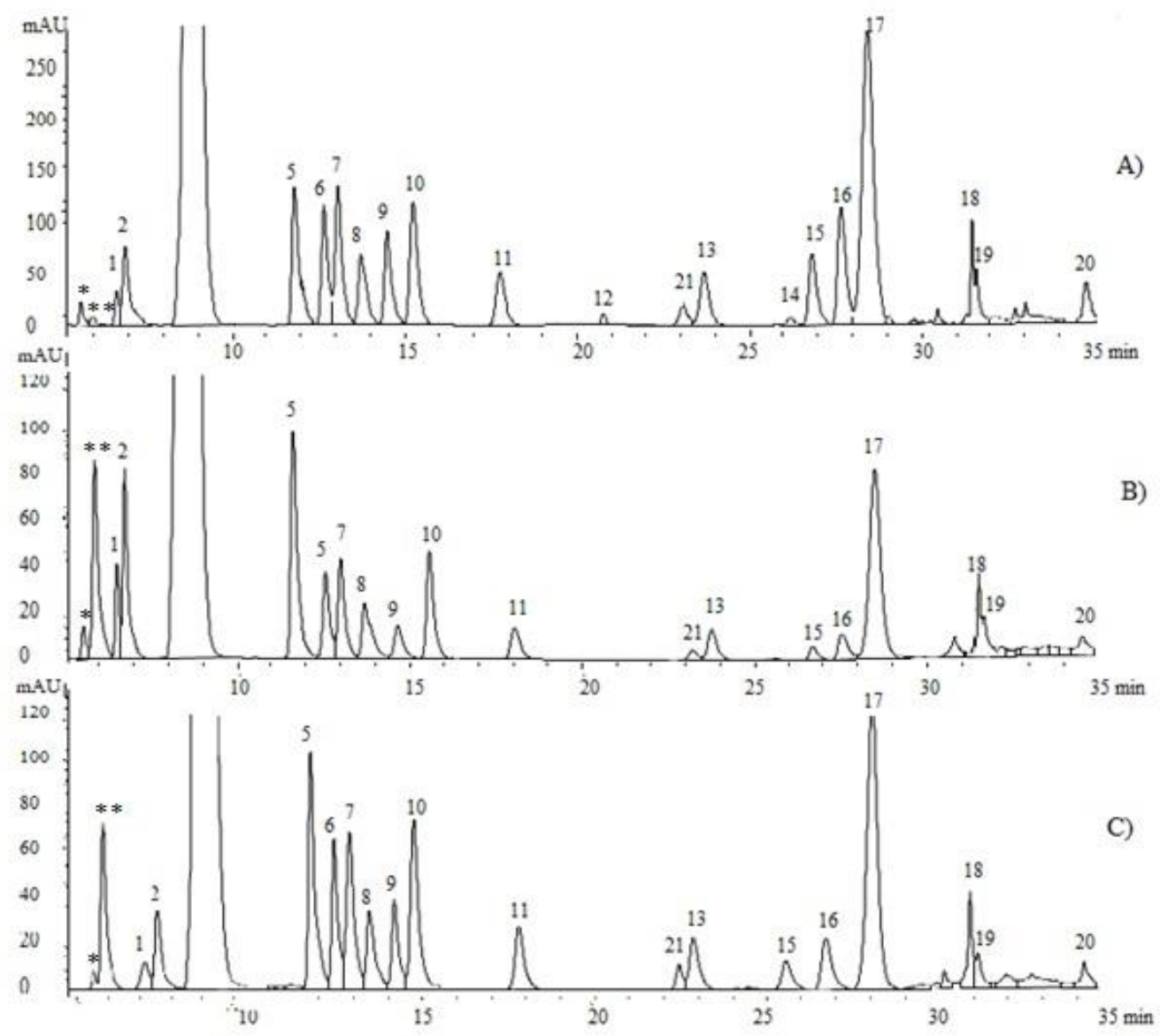

Fig. 4. HPLC chromatograms of dansyl amino acids in A) virgin human hair hydrolysate, B) bleached human hair hydrolysate (bleached with bleaching powder and $12 \% \mathrm{H}_{2} \mathrm{O}_{2}$ ), and $\mathrm{C}$ ) treated human hair with Fibreplex by Schwarzkopf protein treatment (hair was previously bleached with bleaching powder and $12 \% \mathrm{H}_{2} \mathrm{O}_{2}$ ). Peak numbers are the following: $1-\mathrm{Asp}, 2-\mathrm{Glu}, 5-\mathrm{Ser}, 6-\mathrm{Thr}$, 7 - Gly, 8 - Ala, 9 - Arg, 10 - Pro, 11 - Val, 12 - Met, 13 - Leu, 14 - Cys, 15 - Trp, 16 - Phe, 17 - Cys-Cys, 18 - Lys, 19 - His,

20 - Tyr, and 21 - Ile (tentatively identified by comparing retention data with the literature $[33,34]$ and ** were also tentatively identified by comparing retention data with the literature $[35,36])$.

The results from the amino acid analysis in the different hair samples calculated as $\mu$ mol amino acid/gram dry hair are summarized in Figure 5 (results are also given in Table $\mathrm{S} 1$ in the supplemen- 
tary material). This data shows significantly lower amounts of cystine in the bleached hair hydrolysate compared to the untreated one, thus, the primary reaction of oxidizing agents with the proteins of human hair occurs at the disulfide bond of cystine. Degradation during bleaching also appears for all amino acids, but these changes are more evident for the aromatic amino acids (tyrosine, phenilalanine, and triptophane) than for histidine and lysine. The obtained results suggest that the concentration of all amino acids decreases with increasing hydrogen peroxide concentration used for bleaching.

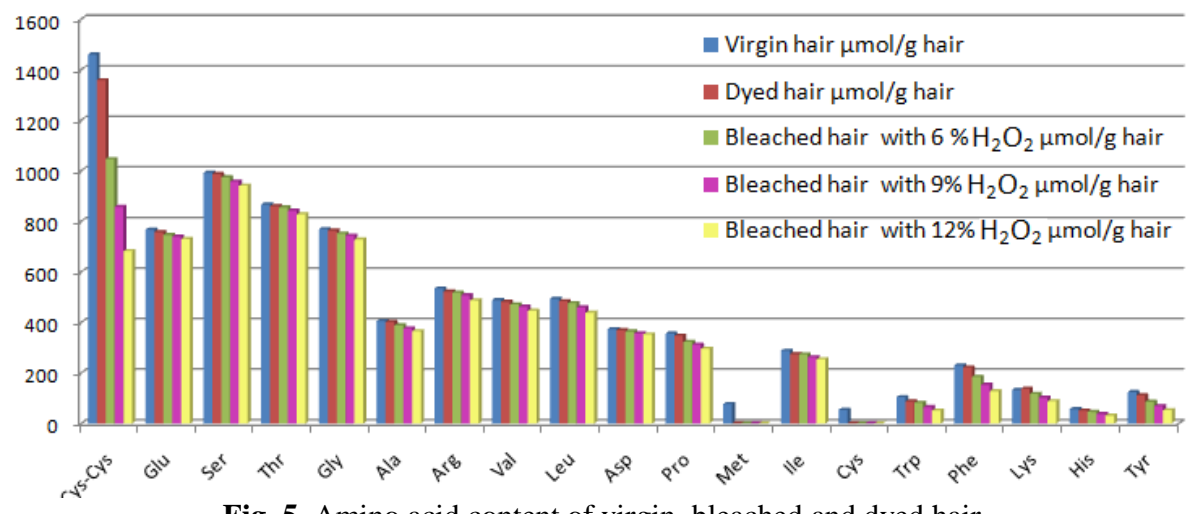

Fig. 5. Amino acid content of virgin, bleached and dyed hair

The oxidative cleavage of the disulfide bond in cystine that occurs during bleaching of human hair is predominantly an $\mathrm{S}-\mathrm{S}$ fission process. Cysteic acid is the end product of this oxidation process, and cysteine oxides are possible intermediates [2]. The minor concentration of cysteic acid is also detected in virgin hair, probably as a result of exposure to sun irradiation (Fig. 4A). According to the literature, cysteine monoxide, dioxide, trioxide and tetraoxide are extremely sensitive to alkaline hydrolysis, but they have been isolated from aqueous acidic medium [2]. In an aqueous alkaline medium characteristic for bleaching, hydrolysis of the cystine oxide intermediates is competitive to their oxidation, and disproportionation of the cysteine oxides may also occur. Accordingly, the peaks marked with $*$ and $* *$ in the obtained chromatograms (Fig. 4) are most likely due to the presence of cisteic acid and some oxides of cystein.
On the other hand, there is no significant difference in the concentration of amino acids obtained from dyed hair compared to untreated hair. These results are due to the absence of strong oxidizing agents. Minor changes in the concentration of amino acids (Fig. 5) are a result of the slight oxidation by hydrogen peroxide, a hair dye ingredient.

\subsection{HPLC analysis of dansyl amino acids in protein treated human hair}

The developed method was then used for an assay of the effects of various hair protein treatments. The results obtained from the amino acid analysis of bleached hair exposed to protein treatments by Fibreplex and Fibreforce (Schwarzkopf) and Keratin treatment (Revlon) are shown in Figure 6 (results are also given in Table $\mathrm{S} 2$ in the supplementary material)

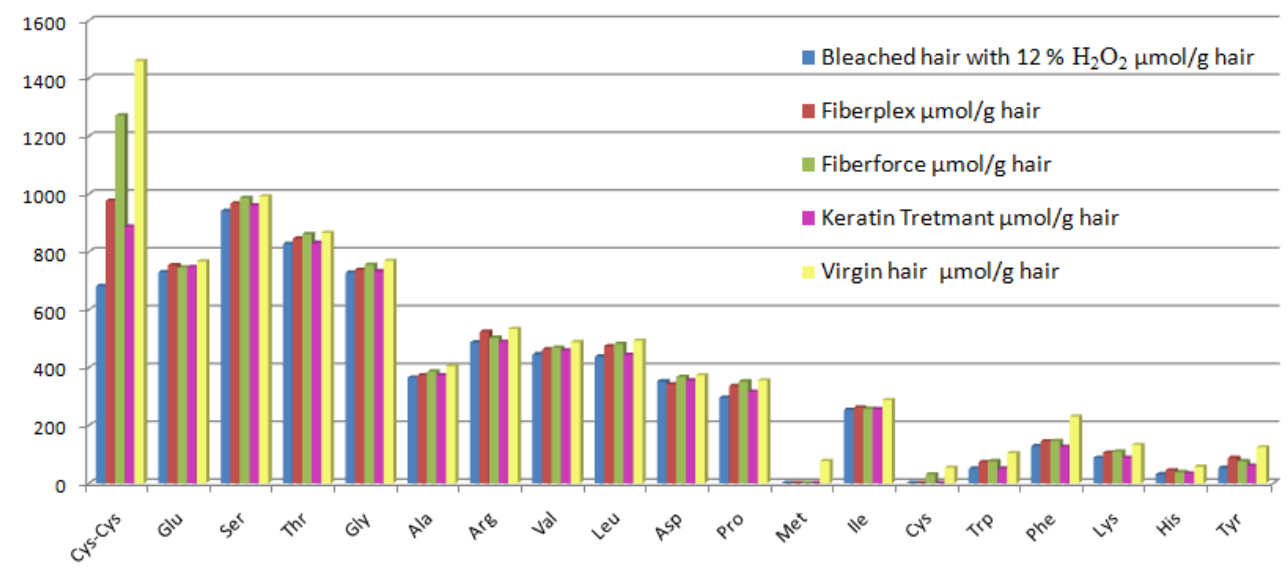

Fig. 6. Amino acid content of human hair treated with different protein treatments 
The concentration of all investigated amino acids increased in comparison to bleached hair (bleaching powder and $12 \% \mathrm{H}_{2} \mathrm{O}_{2}$ ). As can be seen, the most significant increase is observed for threonine, valine, serine, glycine, arginine, aspartic acid and glutamic acid, which are typical for keratin. These results are due to the main component of these treatments based on hydrolyzed keratin with $\mathrm{ab}$ average molecular weight of $2000 \mathrm{Da}$, obtained via alkaline or enzymatic hydrolysis of keratin isolated from sheep or goat wool [37]. Hydrolyzed keratin cannot diffuse into deeper layers because of its size and it is only adsorbed on the surface of the hair shaft. Therefore, these proteins can slowly wash away from the hair. The quality of cosmetic products and their efficiency for repairing dry and damaged hair depends on the concentration of amino acids in hair hydrolysate after protein treatment. In this study, protein treatments by Fibreplex and Fibreforce have proven to be more effective since significantly higher amino acid content has been detected in the treated hair samples.

\section{CONCLUSION}

A new method for simultaneous quantification of amino acids was developed and the protocol was optimized for dansyl derivatization that can be used for amino acids analysis in chemically treated hair after hydrolysis of proteins.

A pre-column dansylation process of hair hydrolysates with an acetonitrile solution of Dns$\mathrm{Cl}$ in alkaline medium ( $\mathrm{pH}$ 9.0) yielded sulfonamide adducts for all investigated amino acids that were determined by UV-DAD detection at $250 \mathrm{~nm}$. In this reaction, cystine gave two dansyl derivatives and a bis-dansyl aduct, the major product, which was used for quantification. The excess reagent was not removed since its intensive peak was completely separated from all dansyl amino acids in the hair hydrolysate.

The best separation for dansyl amino acids in chemically treated hair samples with the RPHPLC method was achieved on an Eclipce XDB C18 column $(150 \mathrm{~mm} \times 4.6 \mathrm{~mm}$, particle size 5 $\mu \mathrm{m})$ using gradient elution with acetonitrile and acetate buffer solution in 5\% acetonitrile ( $\mathrm{pH} 6.3$ ). Baseline separation was achieved with a run time shorter than most previously published HPLC methods for separation of dansyl amino acids.

The results from the amino acid analyses of the treated hair suggested that bleaching chemicals cause degradation of all amino acids and their concentration decreases with increasing hydrogen per- oxide concentration. These changes were most significant for cystine due to its oxidizable disulfide bond. With further exposure to protein treatments, the concentration of all investigated amino acids increased and this was most significant for amino acids typical for keratin, such as threonine, valine, serine, glycine, arginine, aspartic acid, and glutamic acid. Still, there are no records on whether amino acids from hair products replace the ones destroyed during the treatment and whether they are incorporated into the hair structure or just adsorbed on the surface of the hair shaft, giving a shiny and healthy look of the hair fiber. Studies in these directions are in progress.

It conclusion, the proposed method has been shown to be very useful for amino acid analysis in a protein hydrolysate and it can be further used for establishing the amino acid profiles of other protein samples using RP-HPLC after hydrolysis and dansyl derivatization using this optimized procedure.

\section{REFERENCES}

[1] V. N. E. Robinson, A study of damaged hair, J. Soc.Cosmet.Chem. 27, 155-161 (1976).

[2] C. R. Robbins, Chemical and Physical Behavior of Human Hair, $5^{\text {th }}$ ed. SPRINGER, Verlag, 2012. DOI: $10.1007 / 978-3-642-25611-0$

[3] C. Tomes, J. T. Jones, C. M. Carr, D. Jones, Threedimensional imaging and analysis of the surface of hair fibers using scanning electron microscopy. Int. J. Cosmet. Sci. 29, 293-299 (2007).

[4] R. De Cassia, C. S. Wagner, P. K. Kiyohara, M. Silveira, I. Joekes, Electron microscopic observations of human hair medulla, J. Microsc. 226, 54-63 (2007).

[5] J. A. Swift, J. R. Smith, Atomic force microscopy of human hair, Scanning, 22, 310-318 (2000).

[6] S .B. Ruetsch, Y. K. Kamath, L. Kintrup, H-J. Schwark, Effects of conditioners on surface hardness of hair fibers: An investigation using atomic force microscopy, $J$. Cosmet. Sci. 54, 579-588 (2003).

[7] M. V. R. Velasco, A. R. Baby, F. D. Sarruf, T. M. Kaneko, R. E. Samad, N. D. Vieira Júnior, A. Z. de Freitas, Prospective ultramorphological characterization of human hair by optical coherence tomography, Skin. Res. Technol. 15(4), 440-443 (2009).

[8] C. Bouillon, J. Wilkinson, The Science of Hair Care, $2^{\text {nd }}$ ed., CRC Press, Boca Raton, FL, USA, 2005.

[9] J-L. Bantignies, G. L. Carr, D. Lutz, S. Marull, G. P. Williams, G. Fuchs, Chemical imaging of hair by infrared microspectroscopy using synchrotron radiation, $J$. Cosmet. Sci. 51, 73-90 (2000).

[10] A. Kuzuhara, Analysis of structural change in keratin fibers resulting from chemical treatments using Raman spectroscopy. Biopolymers, 77(6), 335-344 (2005). DOI:10.1002/bip.20221. 
[11] B. C. Beard, J. Hare, Surface interaction of quaternary amines with hair, J. Surfact. Deterg. 5(2), 145-150 (2002).

[12] N. Nishikawa, Y. Horiguchi, T. Asakura, I. Ando, Carbon-13 solid-state nmr study of ${ }^{13} \mathrm{C}$-enriched human hair keratin, Polymer. 40, 2139-2144 (1999).

[13] S. S. Sandhu, C. Robbins, A simple and sensitive technique, based on protein loss measurements, to assess surface damage to human hair, J. Soc. Cosmet. Chem. 4, 163-175 (1993).

[14] A. L. Silva, A. S. Nunes, J. L. Gesztesi, Protein loss quantification of abraded virgin and abraded bleached hair according to Bradford assay. J. Cosmet. Sci. 55, 175-179 (2004).

[15] P. Sherovski, G. Stojković, N. Ristovska, Development, validation and application of first derivative spectroscopy ratio method for estimation of Bradford assay, Anal. Biochem. 558, 35-40 (2018).

[16] S. A. França-Stefoni, M. F. Dario, T. C. Sá-Dias, V. Bedin, A. J. Almeida, A. R. Baby, M. V. Velasco, Protein loss in human hair from combination straightening and coloring treatments. J. Cosmet. Dermatol. 14, 204 208 (2015)

[17] S. B. Ruetsch, B. Yang, Y. K. Kamath, Chemical and photo-oxidative hair damage studied by dye diffusion and electrophoresis. J. Cosmet. Sci. 54, 379-394 (2003).

[18] P. Sherovski, N. Ristovska, Electrophoretic analysis of proteins of chemical treated human hair, IJOER 4(5), 38-42 (2018).

[19] C. F. Cruz, C. Costa, A. C. Gomes, T. Matamá, A. Cavaco-Paulo, Human hair and the impact of cosmetic procedures: A review on cleansing and shape-modulating cosmetics, Cosmetics, 3, 26 (2016),

[20] I. Molnftr-Perl, Quantitation of amino acids and amines by chromatography, J. Chromatogr. Libr. 70 (9) (2005).

[21] A. Fabiani, A. Versari, G. P. Parpinello, M. Castellari, S. Galassi, High-performance liquid chromatographic analysis of free amino acids in fruit juices using derivatization with 9-fluorenylmethyl-chloroformate, $J$. Chromatogr. Sci. 40, 14-18 (2002).

[22] T. Takeuchi, HPLC of amino acids as dansyl and dabsyl derivatives, J. Chromatogr. Libr. 70, 229-241 (2005).

[23] P. Molnar, New aspects of the simultaneous analysis of amino acids and amines as their o-phthaldialdehyde derivatives by high-performance liquid chromatography analysis of wine, beer and vinegar, J. Chromatogr. A. 987, 311-22 (2003).

[24] H. Wang, Y. Zhao, H. Jin, H. Zhang, NHydroxysuccinimidyl- $\alpha$ naphthylacetate as a derivatizing reagent for amino acids and oligopeptides in PRHPLC, J. Liq. Chrom. Relat. Tech. 24(20), 3157-3170 (2001)
[25] R. Minocha, S. Long, Simultaneous separation and quantitation of amino acids and polyamines of forest tree tissues and cell cultures within a single highperformance liquid chromatography run using dansyl derivatization, J. Chromatogr. A. 1035, 63-73 (2004).

[26] C. Rutledge, J. Rudy, HPLC qualitative amino acid analysis in the clinical laboratories, A.J.C.P. 5, 614-618 (1987).

[27] Y. Tapuhi, D. E. Schmidt, W. Lindner, B. L. Karger, Dansylation of amino acids for high-performance liquid chromatography analysis. Anal. Biochem. 115(1), 123129 (1981). DOI:10.1016/0003-2697(81)90534-0

[28] M. Fountoulakis, H. Lahm, Hydrolysis and amino acid composition analysis of proteins J. Chromatogr. A. 826(2), 109-134 (1998).

[29] J. M. Wilkinson, CRC Handbook of HPLC for the Separation of Amino Acids, Peptides and Proteins, CRC Press, Boca Raton, 1984.

[30] K. Tašev, V. Ivanova-Petropulos, M. Stefova, Optimization and validation of derivatization method for analysis of biogenic amines in wines using RP-HPLC-DAD, Maced. J. Chem. Chem. Eng. 35, 19-28 (2016).

[31] R. Sethuraman, T. L. Lee, S. Tachiban, Simple quantitative HPLC method for measuring physiologic amino acids in cerebrospinal fluid without pretreatment, Clin. Chem. 50(3), 665-669 (2004).

[32] E. Bayer, E. Grom, B. Kaltenegger, R. Uhmann, Separation of amino acids by high performance liquid chromatography, Anal. Chem. 48(8), 1106-1109 (1976).

[33] X. Kang, J. Xiao, X. Huang, Z. Gu, Optimization of dansyl derivatization and chromatographic conditions in the determination of neuroactive amino acids of biological samples, Clin. Chim. Acta 366(1-2), 352-356 (2006).

[34] B. Reitsma, E. Yeung, Optical activity and ultraviolet absorbance detection of dansyl L-amino acids separated by gradient liquid chromatography, Anal. Chem. 59(7), 1059-1061 (1987).

[35] I. Varzaru, A. E. Untea, T. Martura, M. Olteanu, T. D. Panaite, M. Schitea, Development and validation of an RP-HPLC method for methionine, cystine and lysine separation and determination in corn samples, Ilie.Van.Rev.Chem. 64, 673-679 (2013).

[36] Cs. Albert, K. Lóki, É. Varga-Visi, G. Pohn, P. Sára, J. Csapó: Separation and determination of sulphur containing amino acid enantiomers by high performance liquid chromatography, Krmiva 4, 187-191 (2006).

[37] A. L. V. Villa, M. R. S. Aragão, E. P. dos Santos, A. M. Mazotto, R. B. Zingali, E. P. de Souza, A. B.Vermelho, Feather keratin hydrolysates obtained from microbial keratinases: effect on hair fiber. BMC Biotechnology 13(1), 15 (2013). DOI:10.1186/1472-6750-13-15 